
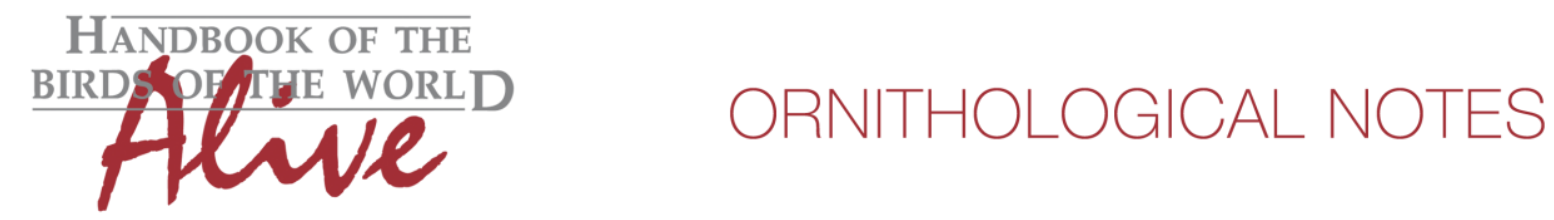

\title{
Notes on the vocalizations of Russet Antshrike (Thamnistes anabatinus)
}

Peter Boesman

In the following we briefly analyze and compare voice of the different races of Russet Antshrike (Thamnistes anabatinus). We also try to quantify the extent of any vocal differences using the criteria proposed by Tobias et al. (2010), as a support for taxonomic review. We have made use of sound recordings available on-line from Xeno Canto (XC) and Macaulay Library (ML).

As it has been suggested that races east and west of the Andes may form separate species (Zimmer et al. 2003), it seems logical to compare voice for these two groups. At the same time, it should be mentioned that the voice description of eastern birds in this source is probably erroneous.

We have made a number of measurements of basic sound parameters:

Group 1: races $W$ of Andes ( $n=8)$

Song is a long downslurred note followed by several shorter downslurred fairly high-pitched notes, starting higher than previous note and maintaining about the same pitch or slightly descending.

Number of notes: $\quad 4-8$

max. freq. $\quad 5400-7600 \mathrm{~Hz}$ (usually on second note)

max. freq. first note $\quad 4400-5700 \mathrm{~Hz}$

Group 2: races $E$ of Andes $(n=8)$

Song is a long downslurred note (often lacking) followed by several shorter downslurred fairly high-pitched notes, usually initially rising and slightly descending at the end.

Number of notes: $\quad 6-10$

max. freq. $\quad 5700-8000 \mathrm{~Hz}$ (usually on a note halfway or near the end)

max. freq. first note $\quad 4000-5700 \mathrm{~Hz}$

While 'typical' songs are quite distinct (Fig. 1), there seems to be quite some variation in voice of eastern races, with some songs nearly identical to western races.

On average, song of birds $E$ of Andes has slightly more notes and slightly higher max.

frequency. The most reliable difference seems to be that the highest frequency usually is NOT on the second note unlike races W of Andes (but also here some exceptions).

Given the small differences, more samples (especially of eastern races) are needed to obtain more precise average and standard deviation values for all sound parameters.

At present, differences can be scored 1 or 2 for 'length in seconds before reaching highest frequency' and score 1 at most for both max. frequency or number of notes.

All in all, vocal difference of the two groups is minor, with a total score of about 2. 


\section{HANDBOOK OF THE \\ Alve \\ ORNITHOLOGICAL NOTES}
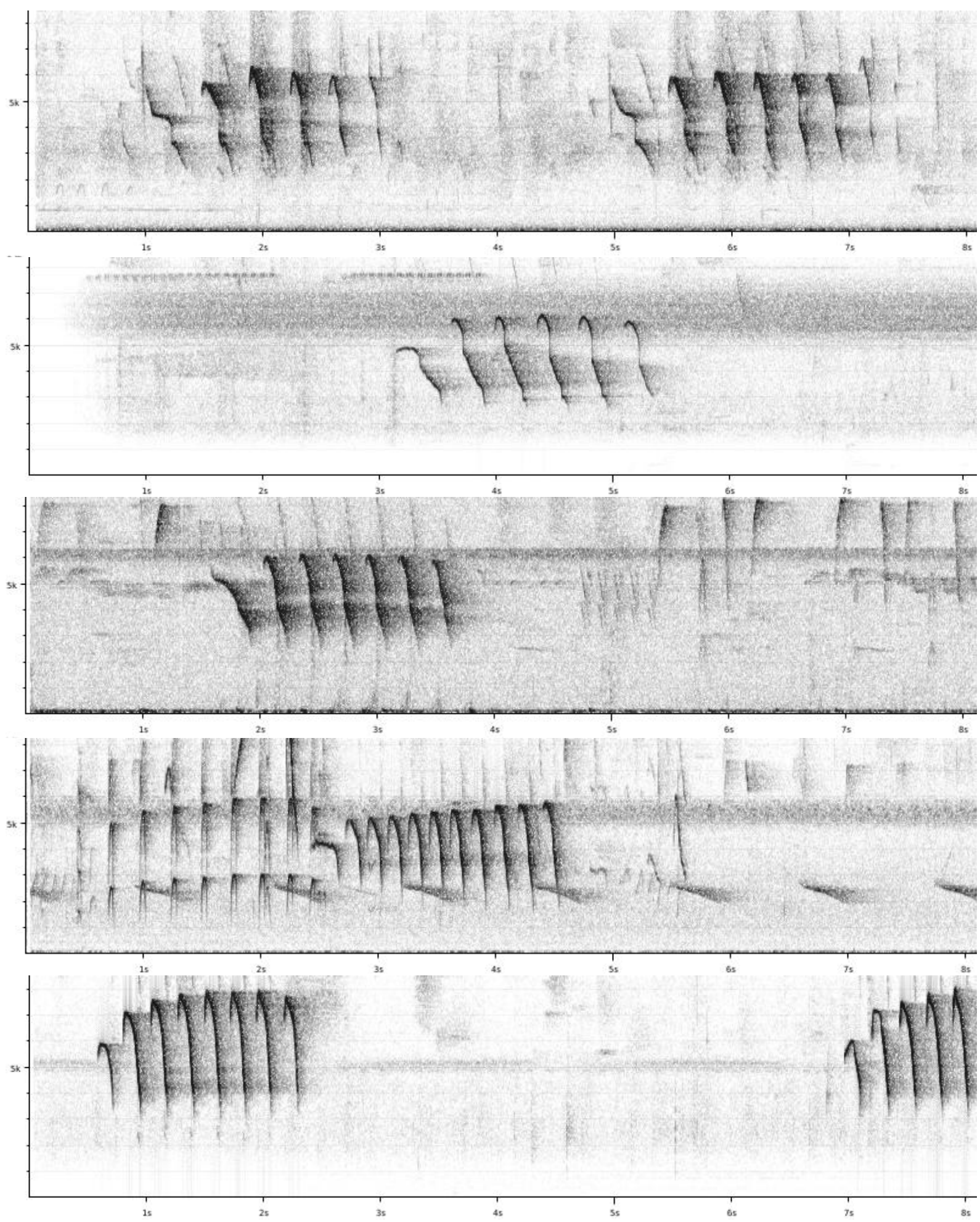

Figure 1: From top to bottom: loudsong W of Andes (Mexico, Panama, W Ecuador) and E of Andes (E Ecuador, N Peru)

As a final remark, we haven't located any recordings of the race gularis, restricted to the Venezuelan/Colombian Andean border) 

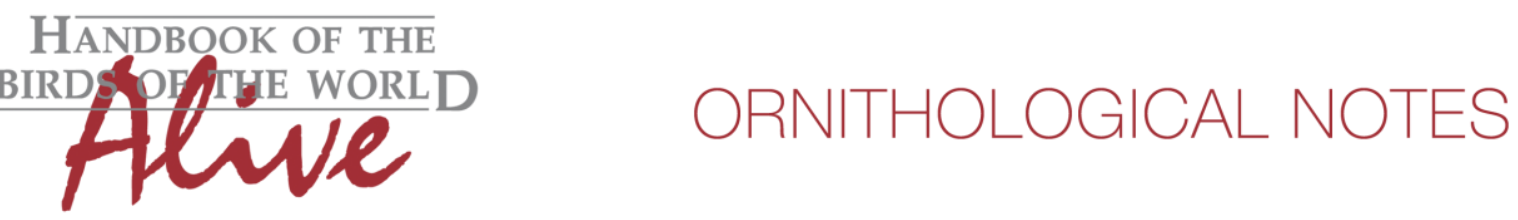

This note was finalized on 30th April 2015, using sound recordings available on-line at that moment. We would like to thank in particular the sound recordists who placed their recordings for this species on XC and ML: Nick Athanas, Peter Boesman, Tayler Brooks, Paul Coopmans, Jerome Fisher, Olaf Jahn, Niels Krabbe, Dan Lane, Mitch Lysinger, Hans Matheve, Scott Olmstead, Mark Robbins, Ted Parker and Andrew Spencer.

\section{References}

Tobias, J.A., Seddon, N., Spottiswoode, C.N., Pilgrim, J.D., Fishpool, L.D.C. \& Collar, N.J. (2010). Quantitative criteria for species delimitation. Ibis 152(4): 724-746.

Zimmer, K. and M. Isler (2003). Family Thamnophilidae (typical antbirds). Pages 448-681 in J. del Hoyo, A. Elliot, and D. A. Christie, editors. Handbook of the Birds of the World. Vol. 8. Broadbills to Tapaculos. Lynx Edicions, Barcelona.

\section{Recommended citation}

Boesman, P. (2016). Notes on the vocalizations of Russet Antshrike (Thamnistes anabatinus). HBW Alive Ornithological Note 64. In: Handbook of the Birds of the World Alive. Lynx Edicions, Barcelona. (retrieved from http://www.hbw.com/node/931948 on 14 May 2016). 